\title{
THE INTERNATIONAL TAX COMMUNITY AND THE POLITICS OF EXPERTISE
}

\author{
Double taxation is not Satan. But when you go to the OECD, and you \\ say double taxation, everyone looks at you like you are the devil. You \\ have one dollar of double taxation, that's the devil.
}

-Former international tax official, Latin American country

Since the origins of the international model treaties at the League of Nations, and the negotiation of some of the earliest bilateral agreements, tax treaties have primarily been the project of a community of international tax practitioners. Many have a common educational and professional background, they meet each other regularly, share in the performance of negotiations among states or between states and businesses, and have a vested interest in protecting the internal coherence of what they see as a technical project against political interference. ${ }^{1}$ There is little pretense during the formal political scrutiny of tax treaties that they are understood by ministers and other politicians in any kind of detail. This chapter therefore turns the attention away from mechanisms that act on such policymakers and toward the experts who develop the multilateral models and negotiate the bilateral treaties themselves.

Whereas the tax treaties myth leads nonspecialists to seek treaties as a way of stimulating investment by lowering investors' tax costs, those with detailed technical knowledge take a different view. For them, tax treaties transmit a series of procedural and content rules concerning the taxation of investors, from the authors of model treaties - a community of specialists revolving around the OECDto the signatory countries. They translate transnational soft-law standards into hard, enforceable law. To be sure, these negotiators have strong incentives deriving from the national sphere, which can produce intense disagreements in bilateral and multilateral negotiations. But they share the long-term project of creating a consistent global approach to taxation modeled on OECD standards, to enhance trade and investment flows, a public good to be diffused as widely as 
possible. ${ }^{2}$ Political considerations are often regarded as exogenous constraints on this project.

To the extent that the dissemination of international standards via tax treaties lowers the risk-adjusted tax cost to investors, bilateral treaties could be conceptualized as a more nuanced version of the tax competition mechanisms discussed in the previous chapter: firms protected by tax treaties' reference to international standards incur an advantage over others that are not. Competition premised on the diffusion of international standards and competition premised on lower short-run tax rates do not always produce the same preferences, however, in terms of either treaty partners or the content of tax treaties. Furthermore, members of the international tax community do not necessarily support a form of competition that applies its standards as a private good, to benefit only investors between treaty signatory countries. They take a more skeptical view about the likely impact of any one tax treaty on investment flows.

This chapter describes the international tax community, the ideas that its members hold, and the means through which it influences policymakers. It considers two implications of the different perceptions of tax treaties in specialist and nonspecialist communities. First, in lower-income countries where there is little institutional memory and the national bureaucracy does not socialize people into the transnational community, civil servants acquire technical knowledge by learning from members of the international community. Expertise may make them more skeptical about the tax treaties myth, and more aware of the costs of tax treaties to their countries. They may also come to share in the international tax community's conceptualization of the merits of tax treaties that transcends this short-term cost/benefit calculation. A second implication is that the ideational difference between specialists and nonspecialists can lead to conflict between the preferences of the two groups within a country. This may prevent it from concluding tax treaties, even if both groups support this course of action in general terms. Specialists may seek to block the conclusion of tax treaties that have been motivated by short-term investment gains, or they may try to negotiate treaties in which political actors, whose consent is ultimately required for signature and ratification, have little interest. The politics of knowledge is a critical part of the political economy of the tax treaty regime.

\section{The International Tax Community}

The history of tax cooperation told in chapter 2 was a "quiet politics" scenario. ${ }^{3}$ As Philipp Genschel and Thomas Rixen describe, the low political salience of 
international taxation from the 1930s to the 1960s had "allowed the experts to craft a compromise solution without major intervention from their political principals." 4 While state preferences no doubt influenced the shape of this consensus, tax historians commonly regard it as having formed among a transnational group of technical experts. ${ }^{5}$ The preface to the report of the League of Nations Committee of Technical Experts on Double Taxation in 1927, one of the regime's foundational texts, stresses that "although the members of the Committee are nominated by their respective Governments, they only speak in their capacity as experts, i.e., in their own name." ${ }^{\prime 6}$ One of the participants in the early League of Nations work, Edwin Seligman, observed that, while at first the technical experts' "concern was primarily to enter into some arrangement which would be politically agreeable to their respective countries ... when they learned to know each other more intimately; and especially in proportion as they were subjected to the indefinable but friendly atmosphere of the League of Nations, their whole attitude changed. Suspicion was converted into confidence; doubt was resolved by the feeling of certainty of accomplishment; and aloofness gave way to warm personal friendship which contributed materially to smoothing out the difficulties."

According to Sol Picciotto, "Perhaps the most important outcome of the interwar years was to begin to create a community of international tax specialists ... a community within which ideas and perspectives as well as economic advantage could be traded." An official history of the OECD model concurs that its "direct parents were ... senior tax officials from European countries."

It is very common to describe these international tax experts as an "epistemic community." In the tax law literature, for example, Allison Christians describes how OECD staff, civil servants representing national governments, and other professional stakeholders "form an intertwined epistemic community that holds an important and influential position in the law-making order." 10 These individuals "diagnose and prescribe tax policy reforms that are informed by, and that play out within, national legal regimes." ${ }^{\prime 1}$ Diane Ring similarly suggests that international tax negotiations are best understood as "epistemically informed bargaining," in which an epistemic community "served as a driving force in the double taxation problem, both in terms of providing a forum for discussion and providing a base of expertise to structure the debate."12 Jason Sharman argues that "tax administrators are enmeshed in a trans-national epistemic community."13 Thomas Rixen, commenting on Stephen Webb, regards the community as being "comprised of tax bureaucrats and business association representatives," having "succeeded in excluding civil society from international tax matters by defining the issues as being 'purely technical' in nature."' 14 
It is easy to see the attraction of this concept for scholars of the international tax regime. In its original formulation, an epistemic community is "a network of professionals with recognized expertise and competence in a particular domain and an authoritative claim to policy-relevant knowledge within that domain or issue." 15 Tax is a technically complex area in which a transnational community claims a monopoly on legitimate expert knowledge. ${ }^{16}$ It advances a policy project through the process of international standard formation that takes place in arcane committees of the OECD, but that ultimately takes the form of national tax laws, mostly via bilateral treaties.

Establishing the causal links between national and international settings is, however, a challenge for the epistemic communities literature, which has tended to focus on demonstrating the existence of particular communities, rather than on understanding how and in what circumstances they are able to influence-or indeed may be influenced by_national policies. ${ }^{17}$ Haas himself suggested their influence came mainly in times of uncertainty and crisis for policymakers, which is unhelpful for the century-long incremental development of the international tax regime. More useful is Haas's notion that policy influence comes in part through "infiltration" of government bureaucracies by community members, but this still characterizes the community as an exogenous influence on national bureaucracies. The concept of an epistemic community is thus ill suited for situations in which bureaucrats themselves form part of the community, where "the decision makers whom members of an epistemic community advise turn out to be themselves." 18

Another theoretical concept with purchase in such situations is that of a transnational policy community, which "refers to a group of officials, whether public or private, that exhibits particular characteristics" including similarities in education and career development, a strong sense of affinity to each other, and a set of interests "defined and articulated in terms of widely accepted principles." 19 Such communities use club settings, in which "members place a limit to the range of actors involved in the making of policy and define what type of actor is relevant."20 To characterize the international tax community, we would need to establish the "widely accepted principles" on which its interests rest, the mutual affinity and common characteristics of its members, and club membership rules. This is not so far from the characteristics of an epistemic community identified by Haas: shared normative and causal beliefs, evaluation of authoritative claims to knowledge, and policy project. Indeed, the transnational tax community exerts influence on national tax policy in the manner of both an epistemic community-through deference to its claim to authority and through infiltrating bureaucracies-and a transnational community, where policymakers' ideas form intersubjectively as part 
of the social group itself. Since the argument of this book is that specialist bureaucrats come to share the worldview of the transnational community, while others in government do not, both mechanisms are of interest.

Describing a transnational policy community, including its gatekeeping rules and underlying norms, does not necessarily tell us how material interests may have shaped it in the past or how they may continue to do so. Such an analysis is assumed by other frames, such as that of a transnational capitalist class. ${ }^{21}$ The international tax community could easily be seen as a part of this group: a collection of bureaucrats and professionals whose shared agenda promotes the globalizing interests of transnational capital. Certainly, the free movement of goods and capital is an underlying normative concern of the transnational tax community, as one might expect given its convergence on the OECD. The choice of transnational policy community reflects an emphasis on two further characteristics, however: the diverse interests within a community that also includes those of governments determined to maximize revenue, and an autonomous logic that sustains the community's normative core and is derived from taxation principles, which cannot be reduced purely to these individual interests or to a capital-friendly logic of globalization.

\section{Ideas within the Policy Community}

The departure point for understanding the international tax community is its original aim of alleviating double taxation. Although this originates with a causal belief - that eliminating double taxation will enhance cross-border trade and investment - the abhorrence of double taxation has become a principled belief with its own normative weight, rather than merely a means to achieve an end. The strength of language used in one of the original League of Nations reports illustrates this: "Double taxation ... imposes on such taxpayers burdens which, in many cases, seem truly excessive, if not intolerable. It tends to paralyse their activity and to discourage initiative, and thus constitutes a serious obstacle to the development of international relations and world production." ${ }^{22}$

The modern-day successor to that report, the OECD model tax treaty, adds that "it is scarcely necessary to stress the importance of removing the obstacles that double taxation presents to the development of economic relations between countries." 23 A report from consultancy firm PWC on international taxation in lower-income countries asserts, with no support, that "overall, double taxation is detrimental to economic development." 24

The OECD model and its associated guidance today have come to embody a consensus view of how to tax cross-border income and capital that transcends the 
original double taxation problem. States now take care of the "heroic" double taxation that motivated the original League of Nations work through their national tax laws, and the words "double taxation" have been removed from the OECD model's title. Nonetheless, it is the alignment of national approaches to international taxation with the standards set out in the OECD model that keeps the instances of double taxation low, and this provides the international tax community with a compelling ongoing claim to authority. "Treaties are the means whereby sovereign states endeavour, usually on a bilateral basis, to harmonize the rules of their national laws," according to a former US negotiator. ${ }^{25}$

Within the community, certain foundational concepts are powerful social conditioning tools, underpinning instances that socialization scholars would recognize as "normative suasion," wherein actors are persuaded to change their positions through recourse to these shared norms. ${ }^{26}$ Double taxation is anathema, and the taxation of multinational firms must comply with the "arm's length principle," which is designed to prevent both double taxation of and tax avoidance by multinational companies. ${ }^{27}$ Policies are evaluated against compliance with these principles above all else, while criteria on which community members may differ, such as particular tax rates or the distribution of taxing rights between different countries, are subjugated below these overriding objectives. In one typical instance at a United Nations meeting, delegates from the US government and the accountancy firm PWC engaged in a lively debate with a speaker from Brazil over whether unconventional aspects of the latter's tax law were consistent with the arm's length principle. ${ }^{28}$ In a fraught debate between members of the UN Tax Committee over a proposed new article to the UN model treaty conferring greater rights to tax on lower-income countries, opponents claimed that the new article would create double taxation, instantly shifting the burden of proof to proponents. ${ }^{29}$

When in 1986 the United States adopted transfer pricing laws that deviated from OECD guidance, its tax policy was roundly criticized by businesses and tax officials from other countries, provoking a decade-long international debate. A short statement by UNICE (Union des Industries de la Communauté Européenne), which represents European businesses, referenced the arm's length principle in nearly every paragraph: various different parts of the US regulation were "a dangerous departure from the arm's length principle," "a threat to the arm's length principle," "at odds with the arm's length principle," and "alien to the concept of arm's length." ${ }^{30}$ The OECD formed a task force to review the US proposals and effectively negotiate with the United States. It concluded that the US rules "could risk undermining the consensus that has been built up over a number of years on the application of the arm's length principle and thereby increase the risk of economic double taxation." ${ }^{31}$ 


\section{Club Membership and Hierarchy}

If this is the ideational foundation of the community, what about the spaces in which shared understandings develop? The boundaries of club membership are most clearly illustrated in accounts of the contemporary politicization of tax politics, many of which focus on how actors such as activist organizations that are not part of this community attempt to influence it, and the community's resistance to such influence. ${ }^{32}$ NGOs, for example, have most successfully influenced deliberations by adopting the mantle of tax expertise themselves. ${ }^{33}$

The burden of participating in numerous international meetings is a common complaint that I have overheard among government officials and business representatives during coffee breaks at such meetings, but it is clear that close social relationships develop as a result. One staff member of an organization that frequently hosts international tax meetings observed during one such coffee break, "These people are friends, they stay at each other's houses." ${ }^{34}$ According to a former treaty negotiator from an OECD country, participation in OECD meetings "was very much a club, people didn't want to lose that gig, a really clubby arrangement." 35 Elements of this "clubbiness" observed at international meetings include delegates' habitual reference to each other in formal discussions by first name, and the clearly warm nature of informal discussions between long-standing members-regardless of their professional affiliation-during breaks and over dinner. It is also clear that such comradeship exists principally among long-standing members of the group from OECD countries, the private sector, and international organizations. Lower-income country delegates — who are newer, attend fewer meetings per year, and generally change over positions more quickly-appeared at the meetings observed to interact primarily among themselves, and with less familiarity. In this sense, the community can be thought of as having a core-periphery structure, with long-standing members from OECD countries forming a close social group, and lower-income country participants occupying a satellite role. It is a common observation that discussions at the UN Committee of Experts are dominated by OECD members who have coordinated their positions in advance, unlike lowerincome country members who act in isolation.

Some country delegates, as well as some external commentators such as prominent lawyers and academics, are particularly influential. ${ }^{36}$ Competition for authority within a community is a key theme of the "linked ecologies" approach, which defines the unit of study in terms of relationships and interactions rather than professions and institutional affiliations. ${ }^{37}$ As Sending and Neumann argue, there is no reason researchers should a priori assume and reproduce the traditionally understood boundaries between realms, such as institutional affiliation or professional qualification; rather, communities should be identified empirically. ${ }^{38}$ Individuals 
with diverse backgrounds and patterns of interaction in multiple ecologies employ "epistemic arbitrage," gaining a more authoritative position through their familiarity with (and in) multiple different ecologies. ${ }^{39}$ This is an especially appropriate concept for international taxation, a field that combines law, accounting, and-to a lesser extent-economics, as well as spanning public and private boundaries and organizing at national and supranational levels. The international tax community's most authoritative participants are able to leverage knowledge from these multiple ecologies, as well as to "be heard" in multiple professional spaces. ${ }^{40}$

Consider first the links between different professional ecologies at a national level. "The concept of a single 'tax profession' or tax practitioner is difficult to comprehend," write Rex Marshall and colleagues; they go on to say, "In practice, the term 'tax practitioner' covers a diverse group of individuals, business structures and professional groups." ${ }^{31}$ Yet these people with different professional trainings, representing organizations on different sides of various distributional conflicts, do identify as part of a common "tax profession." For example, the Chartered Institute of Taxation in the UK was founded in 1930 by a mixed group of accountants and lawyers drawn from private practice and the Inland Revenue, to "promote the study of taxation, hold examinations, facilitate the exchange of information, make representations and establish and maintain a high standard of conduct." ${ }^{42}$ Tax is a hybrid discipline combining law and accountancy, requiring familiarity with both, and individuals with more diverse careers are more often found in positions of authority within formal institutions. ${ }^{43}$ Inside law and accountancy firms, businesses, and revenue authorities, international tax is a niche field within the already specialist field of tax, and those who practice it are small in number, often building closer professional links with fellow specialists outside their own institutions. ${ }^{44}$

Next, consider the public and private sectoral ecologies. While one may naturally assume that governments and businesses may be in conflict over how much of a firm's profits should be paid as tax or retained by the company, in practice international tax policymaking has always been a collective endeavor between the two groups. In their history of the League of Nations years, Graetz and O'Hear describe how the ICC "exercised primary leadership in the movement against international double taxation," lower-income terminology and concepts that were adopted as the basis of subsequent work by the league's technical experts. ${ }^{45}$ In many respects, it was negotiations between the ICC's national chapters that established the contours of an international agreement, ahead of discussions among the league's committee. Resolutions passed by the ICC, according to an observer, were "used as the firm basis on which draft conventions have been built or actual treaties adopted." ${ }^{46}$ Furthermore, the ICC's Double Taxation Committee 
(representing businesses) and the league's Technical Expert committee (representing governments) had overlapping memberships. Thomas Adams, the US government-appointed member of the League committee, chaired a committee for the US Chambers of Commerce as well as participating in the ICC's work; his successor, Mitchell Carroll, was a lawyer advising multinational firms on their tax affairs, as well as working on behalf of the United States at the League. ${ }^{47}$

Today, as noted above, representatives of multinational companies and tax advisers regularly mix at international tax meetings. In addition to private sector representatives' attendance at meetings of the OECD and United Nations, governmental and international organization representatives are commonly in attendance at events organized by tax professionals, such as an annual conference organized jointly by the US Council for International Business and the OECD. ${ }^{48}$ At the national level, in the UK, for example, interactions between governments and private sector lobbyists are frequent, and "the corporate tax reform policy community has a tightly integrated and fairly constant membership," according to John Snape, leading to "an almost astonishing assimilation of professional expertise to the legislative function, born no doubt of many a congenial meeting over coffee and biscuits in Whitehall." ${ }^{49}$ The UK government used secondees from Deloitte to help develop reforms to its laws surrounding taxation of multinational companies, who subsequently returned to the firm to advise private clients. ${ }^{50}$ Although the relationship between government and businesses can be more antagonistic in lower-income countries, there are many similar examples to the UK: Thailand, for example, formed an advisory committee with representation from the "big four" accounting firms to develop more competitive international tax laws; ${ }^{51}$ in Zambia, the Revenue Authority contracted tax adviser Grant Thornton to perform some of its tax assessments. ${ }^{52}$ Advice to the European Commission on international tax law and administrative reforms in lower-income countries was contracted out to accountancy firm PWC. ${ }^{53}$

Added to this is the "revolving door" phenomenon, as individuals move between tax roles in government, the private sector, and international organizations. ${ }^{54}$ A majority of the tax advisers interviewed for this research had worked in the past for governments or tax authorities. The creation of semiautonomous revenue authorities at arm's length from the civil service has led to the appointment of tax commissioners and others in senior roles from the private sector, in countries as far apart as Uganda and Colombia, while the British tax authority has a governing board drawn primarily from the private sector. ${ }^{55}$ The community within which international tax norms are formed and propagated thus permeates the public/ private border, and furthermore, those whose authority is recognized within both ecologies have greater influence as a result. 
A final overlap between ecologies concerns national and international settings. As well as interaction between the different groups mentioned above at the national level, many of the most influential people within national-linked ecologies also operate at the international level. The international ecology is distinct from each of the national ecologies from which its members also hail, and, as Leonard Seabrooke suggests, they are "in a different social space and reconfiguring how they work rather than replicating their national institutions or changing their own to reflect other national institutions." ${ }^{56}$ Seabrooke argues elsewhere that international professional networks "provide a common language to those generating economic policy knowledge and they also stretch and test allegiances to national interests when these conflict with the professions' ideologies and beliefs." ${ }^{57}$

The community of international tax professionals is thus heterogeneous, with a ragged boundary, incorporating people from different countries, professions, and sectors. These individuals are united by a common set of ideas that are embodied in norms such as the arm's length principle, departing from an abhorrence of double taxation. To participate, one must be fluent with the ideas and language of the community, which is complex and technical. Authority within the community is a function of the ability to deploy this language and to leverage experience from within different professional ecologies.

\section{The International Tax Community and the Global South}

Up to now, my discussion of community and ecologies has centered on OECD countries, but almost every country has at least a handful of international tax professionals in government and the private sector who come into contact with the broader international environment. I consider this to be a socializing environment, in which "a process of inducting actors into the norms and rules of a given community" is at work. ${ }^{58}$ When an individual is socialized, they move from a "logic of consequences," based on material incentives and outcomes, to one of "appropriateness," in which actors determine the appropriate course of action by reference to social rules. ${ }^{59}$ Mechanisms of socialization have been divided into three categories: those based on instrumental calculations in response to social incentives; role playing, in which actors emulate those around them in order to fit in; and normative suasion, in which actors are persuaded by others to change their opinions through recourse to intersubjectively derived shared values. ${ }^{60}$ Alastair Iain Johnston distinguishes between a first stage of socialization, in which an actor makes a "conscious instrumental calculation" to follow the logic of 
appropriateness (changed constraints), and a second stage that leads to the "taken for grantedness" of institutional norms (changed preferences). ${ }^{61}$ Michael Zürn and Jeffrey Checkel suggest that compliance with norms based on a purely instrumental motivation may lead to the internalization of norms over time, as a result of the cognitive dissonance created. ${ }^{62}$

Identifying whether preferences and identities have truly changed over timewhether norms have really been internalized—is empirically very challenging. ${ }^{63}$ For example, Kerrie Sadiq describes Australia's integration into the international tax regime as a four-stage process, the first stage of which, she argues, required a conscious decision to recognize the concept of an externally derived, preexisting legal regime. But she maintains that Australian policymakers' actions were based on instrumental calculations about the constraints created by this regime, rather than any change in preferences, "assessing the gains in tax revenue as well as other economic benefits from attracting capital imports as well as international perception against the forfeiture of a certain amount of autonomy and sovereignty." ${ }^{34}$ In this book, I treat statements made by actors in nonattributable interviews as an accurate reflection of the ideas they hold, and I identify logics of both consequence and appropriateness in those statements.

We can consider two ideal-type mechanisms through which influential positions within a bureaucracy come to be occupied by individuals who have been socialized. They differ in terms of sequencing. In the first type, individuals who have already been socialized into a community through professional training or a scientific career subsequently move into policy jobs. For example, Jeffrey Chwieroth finds that countries are more likely to adopt neoliberal economic policies if they appoint to senior posts economists who have trained in an academic environment likely to have socialized them into neoliberal orthodoxy. ${ }^{65}$ The relevant appointments for tax treaties would be senior roles in tax policy within the finance ministry, and tax commissioners, but these roles tend to be occupied by career civil servants who may not have a formal tax training at all. Lower down the bureaucracy, international tax is a niche field that generally develops as a specialism once people are employed within relevant roles in industry or the public sector. If civil servants from lower-income countries take academic training in international tax, they generally do so after they have been appointed. ${ }^{66}$ Such individuals are therefore unlikely to have been socialized into the international tax community before when they began their roles.

A second mechanism, which is more likely to be relevant to international tax, occurs when individuals become socialized in the course of doing their jobs, as they interact with members of a community. For tax treaty officials from lowerincome countries, this is most likely to occur when existing community members 
"teach" newer members about community norms. ${ }^{67}$ Former treaty negotiators, tax lawyers, and international organization staff - all members of the epistemic community-played an influential role in shaping the approach to tax treaty negotiation in Cambodia and Zambia. Teaching and learning may occur through the numerous tax treaty negotiation trainings that are organized for lowerincome countries, usually delivered by the OECD and UN Tax Committee, but sometimes under the auspices of lower-income country organizations such as the ATAF. A United Nations treaty negotiation manual for use at such trainings, for example, contains only a very brief section on the arguments against signing treaties, focusing almost entirely on the arguments in favor. ${ }^{68}$ The international meetings of the policy community, at which lower-income countries are increasingly represented, include a growing number at the OECD and the annual sessions of the UN Tax Committee. Treaty negotiation rounds themselves, which can take one or two weeks, are often described by their participants as teaching and learning environments too. Several interviewees indicated that they had used negotiations with lower-income countries to teach them about the technical detail of tax treaties. ${ }^{69}$ As the tax manager of Maersk, the Danish multinational shipping company, put it: "By negotiating these agreements, they are led into a train of thought about how various forms of tax are administered."70

As André Broome and Leonard Seabrooke argue, learning in such a socializing, specialist context means that "policy space is reduced as actors converge on a shared policy language and learn to solve problems through common diagnostic practices embedded within 'best practice' policy norms." curve" leads to an equal and opposite "policy curve," as the logic of appropriateness circumscribes possible policy responses (figure 4.1a).

In the case of tax treaties, however, policy autonomy requires a degree of technical knowledge, without which policymakers will either be unable to analyze policies correctly or will be reliant on external sources of expertise. Learning may lead to socialization, as Broome and Seabrooke suggest, but in these circumstances it can also create policy space as the technical knowledge gained by bureaucrats allows them to question their own prior assumptions and those implicit in the knowledge imparted by the international community. I suggest that the "policy curve" is therefore shaped like a normal distribution (figure 4.1b). With a small amount of capacity, individuals resort to nonspecialist norms, which close down policy space. Fully absorbing specialist norms through socialization restricts policy space in a different way. Yet considerable learning is nonetheless necessary to maximize policy space.

This dynamic can be observed in the cases discussed in chapters 6 and 7 . Zambia and Vietnam negotiated large numbers of treaties without first establishing a baseline of technical knowledge. They were unable to critically analyze the 


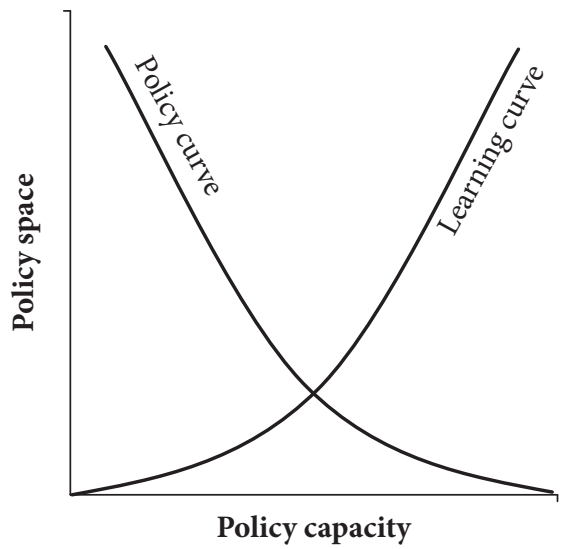

FIGURE 4.1A. Policy space and capacity-building curves

Source: Based on André Broome and Leonard Seabrooke, "Shaping Policy Curves: Cognitive Authority in Transnational Capacity Building," Public Administration, May 2015, https://doi.org/10.1111/padm.12179.

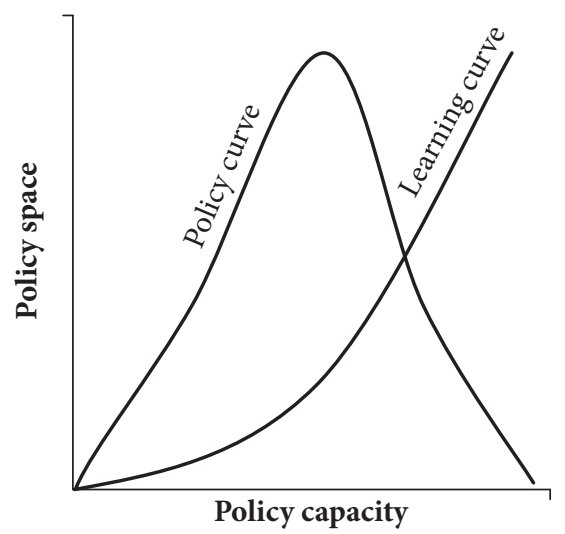

FIGURE 4.1B. Policy space and capacity-building curves for tax treaties Source: Author.

circumstances in which tax treaties were likely to have significant benefit and costs to them, or when or how to counter the negotiating preferences of higher-income countries. There are signs that, by the 2000s, technical officials from both countries had internalized international norms, although these officials' autonomy over treatymaking differed significantly. Yet the beneficial impact of strong technical capacity on policy space is visible in Zambia's renegotiations to fix past mistakes and Cambodia's careful early negotiations. 


\section{Epistemic Authority in Lower-Income Countries}

The previous section considered how the international tax community may influence the ideas held by specialist bureaucrats. But such mechanisms can only influence bureaucrats at a junior level such that their remit is specialized. For nonspecialists, including those in more senior bureaucratic and political roles, we need to consider how the community influences people outside its own boundaries. Such influence is widely expected to be greatest under conditions in which policymakers experience significant technical uncertainty, but the means through which they exert influence is not well understood. ${ }^{72}$

Taxation is entirely a legal construct, which carries with it a certain inevitable deference to tax professionals, who are seen to monopolize expert knowledge not just on its interpretation but on its very nature. ${ }^{73}$ So it is not surprising that concerns about the domination of international tax policy by a technical community are also highlighted by critical legal scholars writing in the Bourdiesian tradition. The starting point for this is Pierre Bourdieu's article describing a juridical social field as "the site of a competition for monopoly of the right to determine the law.” As he argues:

It divides those qualified to participate in the game and those who, though they may find themselves in the middle of it, are in fact excluded by their inability to accomplish the conversion of mental space-and particularly of linguistic stance-which is presumed by entry into this social space. The establishment of properly professional competence, the technical mastery of a sophisticated body of knowledge that often runs contrary to the simple counsels of common sense, entails the disqualification of the non-specialists' sense of fairness, and the revocation of their naïve understanding of the facts, of their "view of the case."

This view describes with prescient accuracy the tax community's interactions with the broader political and public space. John Snape regards international corporate taxation as an example of how "private regulation is transformed into public law with the complex reasonings of specialized professional disciplines as its chief characteristic." 75 Sol Picciotto sees a resonance for international tax in the way that "law operates to defuse social conflicts and depoliticize them, shifting political and economic conflicts on to the terrain of debates over the symbolic power of texts." $76 \mathrm{He}$ argues that the cohesiveness of the international tax "interpretive community" of stakeholders from organizations with apparently conflicting interests is maintained by elaborating new rules that maintain a broad 
ongoing consensus, and by "limiting the membership of the interpretative community and trying to ensure that they are like-minded." ${ }^{\prime 7}$ Secretive meetings in the 1960s and 1970s have given way to public discussions to which access is instead restricted by the technical complexity of legal rules and the language used to debate them. This leads to a self-reinforcing in-group of people "able to invest in learning the arcane terminology and linguistic techniques familiar to that group." ${ }^{78}$ This linguistic gatekeeping, he argues, is bolstered by a social and financial pressure not to question the community's foundational principles.

Certainly, where there is political involvement in the specifics of multinational corporate taxation, this is an exception rather than a rule. ${ }^{79}$ As Pepper Culpepper emphasizes, civil servants and business representatives may exercise a de facto veto over political actors because of the disparity in knowledge. Business power in "quiet politics," he argues, "is not primarily because of the structural power to disinvest, which Lindblom emphasized. It is instead because they [businesses] know the facts on the ground, and that expertise is extremely valuable in negotiating with other members of the policy subsystem. On the rare occasions when politicians turn their attention to typically low salience areas, they enter with an asymmetry of expertise vis-a-vis the representatives of business." ${ }^{80}$

Charles Lindblom refers to the complicity between civil servants and their private sector interlocutors in his classic analysis of business power, in which he argues that one strategy employed by businesses is to attempt to keep policy issues below the political radar. He suggests that civil servants will often support such efforts because "they are caught in a potential crossfire between privileged controls and polyarchal controls." ${ }^{\prime 1}$ Ash Amin and Ronen Palan also emphasize that there is no reason to assume a priori that actors within government bureaucracies and multinational firms are in an antagonistic relationship. ${ }^{82}$

Beyond international tax rules, tax policy in lower-income countries has historically been shaped by an outside professional community. There is a critical strand of literature on tax reform that describes how a "tax consensus" developed among development policy advisers in the 1980s and was transmitted to lowerincome countries through conditionality and technical assistance. According to Odd-Helge Fjeldstad and Mick Moore, this consensus focused on the elimination of trade taxes and their replacement with the VAT, as well as a bureaucratic reform: the creation of semiautonomous revenue authorities that were not under the direct control of finance ministries. ${ }^{83}$ This view, they argue, formed among "an epistemic community of taxation professionals, employed in national tax administrations, in consultancy companies and in international financial institutions, and organised in regional and global professional associations" during "a period of unusually radical tax reform in the developing world since the 1980s." 84 "The key factor," 
writes Miranda Stewart, "is the development of an international consensus, or 'norm', of tax reform and policy driven largely by the international institutions, and propounded by non-government tax experts." 85

Three main concerns are highlighted by authors discussing this tax consensus: its close association with the neoliberal Washington consensus, its "one size fits all" approach, and, crucially, the depoliticization of decisions with important distributional impacts, which critics argue should fundamentally be part of the democratic process. ${ }^{86}$ Lisa Philipps describes how "tax and budgetary issues are frequently constructed as technical matters that can be resolved rationally according to economic, mathematical or other ostensibly neutral principle," with policymaking processes dominated by technical experts despite the political nature of outcomes. ${ }^{87}$ Stewart concurs that "tax reform projects have been mass-produced and have spread rapidly across the globe through broad, superficial, and generalized tax policy recommendations grounded in the consensus.... The contemporary mass production of tax reform militates against any real domestic political participation in the determination of tax policies and laws in the countries undergoing reform." $\$ 88$

This literature has focused on domestic tax reforms, in particular the elimination of trade tariffs and the introduction of VAT, during the past three decades. Yet international institutions and experts play a similar driving role in the international tax reforms adopted by lower-income countries, in particular with respect to transfer pricing and tax treaties.$^{89} \mathrm{~A}$ review of lower-income country tax systems commissioned by the European Commission from PWC, for example, urges that "donor support initiatives should eventually aim at lifting the TP [transfer pricing] legislation and its application in developing countries to a common international standard. In our opinion, this is vital to reduce economic uncertainty and foster investment and growth." ${ }^{90}$ In Vietnam, the business lobby group the Vietnam Business Forum (VBF) regularly urges the government to "align ... Vietnam tax policy with international practice," calling in 2014 for it to "study and provide guidance base on the description and regulation about permanent establishment under international practice and standard as the UN and the OECD."'1

The international tax community can thus be characterized as a transnational policy community whose ideas are formed intersubjectively in the social context it creates. Through formal professional competence, high technical and linguistic barriers to participation, and its own pivotal role in standard setting, the community claims a monopoly on the "correct" way to do international tax. Because tax is a legal construct, this claim extends to defining its every aspect. The community itself is dynamic and fluid, the nexus of several overlapping ecologies: accountancy and law, private and public, national and international. Many of the leading 
roles in international tax are played by individuals who have authoritative positions within these multiple ecologies. The community influences policy in part by socializing bureaucrats who occupy relevant specialist positions into its norms, and in part through nonspecialist policymakers' deference to its expertise. Policymakers' technical uncertainty, the emphasis in the epistemic communities literature, certainly leads them to defer to the community, yet the community itself actively creates such uncertainty, through the proliferation of ever-greater complexity.

\section{The OECD as a Site of Authority}

It is impossible to discuss international tax without discussing the OECD. Its hegemonic status is widely recognized by tax law scholars, and so a theoretical understanding of the organization is essential for this book..$^{92}$ Yet in comparison with other international organizations, international relations scholarship on the OECD is relatively limited..$^{93}$ Work on the OECD's role in international tax relations has generally been focused on its initiatives to target harmful tax practices and tax havens, which are largely distinct from its work on tax treaties. ${ }^{94}$

International organizations are of particular importance in the field of socialization, both as providers of advice and, along with their associated communities, as settings for socialization. ${ }^{95}$ According to Martha Finnemore, international organizations should be considered as autonomous actors, "shapers of actors or interests," above and beyond the sum total of their member states. ${ }^{96}$ She points to the "teacher" role fulfilled by international organizations, "according them more autonomous and causal status, particularly as shapers of actors and interests. ${ }^{.97}$ Friedrich Kratochwil and John Ruggie argue that "in the international arena, neither the processes whereby knowledge becomes more extensive nor the means whereby reflection on knowledge deepens are passive or automatic. They are intensely political. And for better or for worse, international organizations have manoeuvred themselves into the position of being the vehicle through which both types of knowledge enter onto the international agenda." ${ }^{\text {98 }}$

The OECD's model tax treaty and associated guidance have a hegemonic status, forming the basis of all bilateral tax treaties. Variations, such as the UN model tax treaty, still take the OECD model as their point of departure, although they adapt it independently. Yet the OECD has achieved this outcome not as a purveyor of hard law but rather as a site in which soft-law instruments are created and promulgated. For this reason, much scholarship on the OECD focuses on its ideational leadership. As Charles Nelson wrote as early as 1970: "The OECD is important not for the decisions it makes but for the decisions it prepares.... There are very few 
important international economic problems which the OECD can legitimately resolve.... This is the most important single characteristic of the OECD. The major decisions prepared within it are inevitably formalized and carried out elsewhere: in the IMF, in the GATT [general agreement on tariffs and trade], in the UNCTAF [sic; United Nations Conference on Trade and Development], in the World Bank, or through traditional diplomatic channels." ${ }^{\prime 9}$

Bengt Jacobsson suggests that the OECD has a meditative function, through which standards are developed, and an inquisitive one, its distinctive peer review process through which states' compliance with those standards is assessed. ${ }^{100}$ While the peer review process is a part of the OECD's taxation work, until recently this was in areas other than tax treaties, and so it is on the meditative role that this discussion will dwell. It is worth noting, however, that the OECD's authoritative position as the grouping of the world's most "advanced" democracies occupies a mutually reinforcing role with respect to its peer review process. Peer reviews simultaneously rely on and bolster the OECD's position as a source of authoritative knowledge about how an advanced economy should behave, because it can "modify the reference groups of national bureaucrats, their aspirations, and their behaviour." 101

An influential paper by Martin Marcussen segments the OECD's ideational role into five categories: an artist, which formulates, tests, and diffuses policies; an agent, which transfers ideas from more prosperous to less prosperous states; an agency, which takes emerging ideas from states, develops them, and then sells them back in a more refined form; an arbitrator, through which civil servants are socialized; and finally, an authority, used by states to back up their positions. ${ }^{102}$ Each of these roles helps explain the OECD's central role in the world of tax treaties.

Consider first the artist role. The OECD is the place in which international tax standards are formulated and reformulated, since it inherited the responsibility for the model tax treaty from its predecessor the OEEC. Whenever tax specialists within its member states identify a need for new or changed standards, it is to the OECD that they turn. This was the case in the late 1990s, when states began to be concerned about tax havens, and it applied again in 2012, when corporate tax avoidance rose up the political agenda. ${ }^{103}$ Arthur Cockfield suggests that this is part of a trend toward doing the technical work on new standards at the OECD first, rather than first developing standards at the national level and then using the OECD as a forum to reconcile different approaches. "Because of the history of cooperation along with more recent efforts, it may be the case that the OECD member states have learned to trust the OECD process to the point where they are increasingly prepared to accept the OECD's leadership in resolving other areas 
of international tax policy concern, including binding multilateral mechanisms in limited areas such as transfer pricing arbitration." 104

Studies of the OECD have emphasized the informal interaction between specialist bureaucrats as a forum for socialization since its early days as an organization. Henry Aubrey emphasized that the formal part of meetings and the "informal contacts in the corridors and over meals" led to "mutual appreciation and trust" between civil servants. ${ }^{105}$ Marcussen, citing Gunnar Sjöstedt, describes how officials in OECD deliberations "develop a common language . . . start using the same kind of causal reasoning," and "develop a common selective perception of the world and they start to employ a common frame of reference and a common worldview. The latter helps them to define what can be considered as a relevant problem in the first place and which instruments can legitimately be employed to solve this problem." 106

Scott Sullivan, in an authorized account that presumably reflects the OECD's self-perception, describes how OECD committees "serve as a crucible for its members' future actions. ... In the corridors and coffee bars between sessions, officials with similar interests but very different backgrounds meet, argue, forge friendships." 107

A focus on the OECD's members and their interactions through the OECD, however, risks underspecifying the entrepreneurial role of the OECD secretariat. For Rianne Mahon and Stephen McBride, the organizational culture within the OECD is an important contributor to its meditative function. "OECD staff conducts research and produces a range of background studies and reports. In this, they draw on their disciplinary knowledge, supplemented by what Dostal refers to as an 'organizational discourse' - 'claims encapsulating long-term political projects as defined by the organization in question'. The latter reflects the effects of organizational learning." 108

A survey of career histories of staff from the OECD's Centre for Tax Policy and Administration (CTPA), forty-five of whom had a profile on LinkedIn, illustrates that the OECD tax bureaucracy reflects the public-private policy community. Some 42 percent of its staff came to the OECD from multinational businesses, accountancy firms, and law practices, while 58 percent worked in finance ministries and revenue authorities; when full career histories were taken into account, 75 percent of CTPA staff had worked in tax specialist roles in both the public and private sectors at some point. ${ }^{109}$ The OECD secretariat is therefore the embodiment of an expert community whose reach transcends the public and private boundaries. As Jason Sharman argues, the normative weight of the OECD's output rests on its "technocratic identity ... as an international organisation composed of 'apolitical' experts." 110 
Secretariat staff and civil servants interact frequently through the OECD's various tax committees, working parties, and forums. For Allison Christians, it is this tripartite interaction among national government representatives, experts from academia and business, and secretariat staff (largely drawn from the first two groups) that defines the OECD's way of working. "These tax policy groups form an intertwined epistemic community that holds an important and influential position in the law-making order. Together, the CTPA (OECD employees) and the CFA [Committee on Fiscal Affairs] (public servants or national representatives) diagnose and prescribe tax policy reforms that are informed by, and that play out within, national legal regimes."111

If the internal milieu of the OECD is a potential socializing context for the tax profession, the external-facing aspects of Marcussen's typology also seem highly apposite. He describes the OECD's "agent" role as the manner in which it transfers policy from more prosperous to less prosperous nations. ${ }^{112}$ As a socializing forum and a promulgator of standards, it is not just that the OECD is a focal point for other states, as Thomas Rixen argues, but also that its standards are associated with the "advanced" reputation of its member states. ${ }^{113}$ As Tony Porter and Michael Webb write, the OECD's technical work "is reinforced by the diffuse sense that the OECD's knowledge is an expression of the best states' best practices." 114

This authoritative role toward nonmembers is established not merely passively by the OECD but also through active outreach. This takes two forms: civil servants from lower-income countries are invited to participate in various forums in Paris, and the OECD also engages in sensitization and capacity-building work. Since the mid-1990s, the CTPA has maintained an active program of outreach to lowerincome countries, based on training workshops and seminars with civil servants, many of whom went on to lead their country's tax treaty negotiations. ${ }^{115}$ Such outreach is premised on the technical superiority of the OECD's international tax instruments, as demonstrated by their adoption across its members and more widely. A prominent policy paper from the OECD states: "There is already a significant amount of work being done by the OECD and other international organisations to support developing countries to address these [international tax] challenges. This work aims at disseminating effective international standards, improving access to data and information, building capacity and assisting in tax audits." 116

Another part of the OECD's meditative function, as described by Marcussen, is the manner in which it is cited as an authority by its members (and, we might say, by other actors in the international tax milieu). For example, a consultancy report on transfer pricing written for the European Commission by PWC states: "The OECD Guidelines could serve as common global standards for TP and we would advocate that developing countries orient themselves to these standards 
when adopting and implementing TP legislation.... The selected countries should particularly draw attention to the development of a network of DTAs. This can foster the local investment climate by providing a legal mechanism to address potential cases of double taxation." 117

The OECD is the guardian of concepts that are foundational to the international tax community, but it is not the only organization in which the tax expert community operates. Some regional organizations of lower-income countries have developed their own model treaties, but in every case these organizations use the OECD's model treaty as their jumping-off point. ${ }^{118}$ The UN Tax Committee, a group of twenty-five tax treaty negotiators (acting, like the League of Nations group, in their personal capacity) produces its own model treaty that is supposed to be explicitly designed to take into account the special needs of lowerincome countries. The UN model treaty differs from the OECD model in the wording of a number of clauses, some of which can be found in a majority of tax treaties signed by lower-income countries. ${ }^{119}$ In practice, however, the committee's debates exist within a framework of legitimate dissent, whereby differences in interests between higher-income and lower-income countries are tightly contained within the overall framework of the standards formulated by the OECD, such as the arm's length principle, which are not questioned. Many of the senior roles within the UN committee are occupied by individuals who also play leading roles within the various OECD working parties. ${ }^{120}$

More importantly, the UN committee serves as a forum for socialization of lower-income country officials. This objective is set out clearly in an internal UK civil service document from the 1970s: "Our view, which is shared by the Americans and the Dutch, has been that it is of little use to try to 'educate' developing countries-at the United Nations Expert Group on tax treaties and elsewhereabout acceptable international fiscal standards if, when it comes to the crunch, we are prepared to sacrifice principle in order to secure an agreement."121

We can see, therefore, that the OECD is at the heart of a tax ecosystem that incorporates other international organizations, business groups, and countries, held together by the glue of a community of tax professionals who are simultaneously participants in these different organizations' work. The OECD's central position is a function of two mutually reinforcing perceptions: the technical superiority of its standards, and their endorsement by the world's most advanced economies, the members of the OECD. The international tax community's emphasis on tax treaties as the correct way of establishing the tax treatment of multinational companies gains authority from the organization's wider economic policy authority. 


\section{The Tax Policy Community and the Making of Tax Treaties}

This section takes the prior analysis and situates it in the national-level tax policymaking procedures, in particular the process of treaty making. That process, from the initial policy considerations through to ratification, is guided in almost every country by a small team of technical professionals. The formation of a strong specialist international tax unit within a finance ministry or revenue authority, with institutionalized links to the OECD, UN Tax Committee, or other socializing environment, is likely to determine the extent to which officials learn. But these professionals' autonomy is circumscribed by a number of veto points, at which political or other bureaucratic actors may have some formal or informal ability to block the progression of the treaty. ${ }^{122}$ While the process varies across countries, these veto points are generally ex ante negotiating authority, opening negotiations, agreement at official level ("initialing the draft"), signature, and ratification. If the preferences of specialists and nonspecialists do not align, the ability to negotiate a treaty is likely to depend on control of those veto points.

Such tensions have been inherent since the very first tax treaty to be negotiated between two countries-Prussia and the Netherlands in the 1910s. First, the treaty was not ratified by the Dutch side because of objections from the business community to its information-sharing clauses, which only emerged at the last minute when the outcome of negotiations was made public. ${ }^{123}$ The treaty was described as a "personal project" of lead negotiator Jan Sinninghe Damsté. An attempt at renegotiation stumbled because, according to a communication from the Dutch ambassador to Germany, "this matter was previously dealt with by the Minister of Finance, and ... the current official did not understand these matters." ${ }^{24}$

Let us begin at the policymaking level. In her study of business power in corporate tax policymaking in Latin America, Tasha Fairfield argues that "administrative constraints" and "technical principles" limit the businesses' structural and instrumental power over tax policy at the national level. ${ }^{125}$ In international tax, even at the national level, it is the transnational policy community that provides the technical language, norms, standards, and guidelines that frame debate, embodied in the OECD model. The model certainly delimits the set of acceptable options in the minds of policymakers, to the extent that it is argued to have a "soft law" status. ${ }^{126}$ Kerry Sadiq characterizes the process of international tax policymaking in Australia as follows: "The Australian Federal Government inherently accepts the existence of an international tax regime and adopts both the international tax policy and practice aspects embodied in that regime through its domestic rules and double tax treaties." 127 This is also the case outside the OECD, where policymakers may feel constrained to follow international best practice. ${ }^{128}$ 
Few countries have an explicit policy regarding whom they will negotiate with. ${ }^{129}$ As a result, decisions about whom to negotiate with are made by civil servants, often with little ministerial oversight. In one country, a treaty had been negotiated by a previous tax commissioner, understood by current officials as a "personal project" based on his personal connections to the treaty partner, and quietly shelved when the commissioner was replaced. Seven years later, when its existence was uncovered by a senator, it was ratified, to the consternation of the revenue authority. ${ }^{130}$ In another, ministerial approval to open negotiations was fully understood to be a box-checking exercise and had never been declined. ${ }^{131}$ Uganda even initiated a review of its treaty network with the aim of soliciting some political guidance where previously decisions had been made entirely by tax officials. $^{132}$

As discussed in the previous chapter, tax treaty negotiators from most capitalexporting countries consult at the prioritization stage, with businesses and with other government departments. In some countries, the decision to enter negotiations requires direct ministerial approval, while in others ministerial involvement comes later, once the text is ready for signature or even further down the line. The UK case study in chapter 5 records how the minister responsible sought to have approval of treaty texts before signature, rather than simply being shown them before he proposed their ratification to Parliament.

Negotiators' autonomy is in part circumscribed by the law that gives them force. For example, in the UK, the Taxation (International and Other Provisions) Act of 2010 defines the double taxation that is to be relieved by tax treaties, and specifies the taxes to which the mechanism can apply. To give effect to an agreement that exceeds this mandate, the law would have to be changed, as it was in the case of the UK-Brazil negotiations (discussed in chapter 5). Within the legal parameters, only new precedent generally requires ministerial approval. ${ }^{133}$ In contrast, section 88 of Uganda's income tax act merely states that an international tax agreement "shall have effect as if the agreement was contained in this Act." Uganda's chief negotiator indicated that the country's review of its tax treaties was in part designed to give a political steer where previously negotiators had only their own opinions to guide them in negotiations. ${ }^{134}$

An important addition to this discussion is the role played by model treaties in setting the parameters of negotiations. OECD member states have their own national model treaties, which are largely used in private to set out their opening negotiating position, ${ }^{135}$ and which are published by a small number of countries. ${ }^{136}$ They also adhere to the articles of the OECD model convention, which they have negotiated among themselves in advance, except where they have specified reservations to its text. ${ }^{137}$ Itai Grinberg argues that "at least within the OECD, tax treaty negotiators feel substantially constrained to accept OECD Model Treaty 
provisions in their future negotiations with other sovereigns." 138 Other countries may also refer to regional models, such as the COMESA, SADC (Southern African Development Community), and EAC (East African Community) models in Africa or the ASEAN model in Southeast Asia. These models are generally formulated by the treaty negotiators themselves, in particular at the OECD, where a dedicated working party of civil servants updates the model convention, which is then approved by the CFA, made up of "high-level officials in national treasuries and tax administrations." ${ }^{139}$ The process of modifying the OECD model has become more consultative, with business groups submitting comments on published drafts or participating in working groups. ${ }^{140}$ Political oversight, however, remains minimal for the most part. ${ }^{141}$ The UN committee's members are formally acting in a personal capacity rather than on behalf of their countries, and the model they draft has no intergovernmental status. Notably, the COMESA model treaty was drafted by European private sector consultants, while the accountancy firm KPMG drafted an ASEAN position on tax treaties. ${ }^{142}$

Tax treaty negotiations are generally led by a country's finance ministry or its tax authority, with the exact division of labor depending on the institutional structure. In countries such as the UK and Cambodia, it is the tax authority that leads, while in others such as Zambia and the United States, responsibility lies with the finance ministry, although the revenue authority may also participate in negotiations. ${ }^{143}$ Foreign affairs and investment promotion ministries also often participate but contribute little, if at all. In the UK, for example, the Foreign and Commonwealth Office (FCO) approves treaty texts before they are signed, but in general its only input is on the definition of the contracting states. ${ }^{144}$ In all the case studies in this book, negotiations were led by officials from finance ministries or revenue authorities, with varying degrees of specialism in international tax; in wider interviews, a handful of examples were given of negotiations led by other government ministries, such as in one case an investment promotion authority. ${ }^{145}$

Tax treaties are intergovernmental agreements that, once signed, become a part of their signatories' tax laws. Ratification follows different procedures in different countries. Typically, in lower-income countries, tax treaties are ratified by the cabinet, with no parliamentary approval. This is the case, for example, in Uganda, where treaties are merely laid before parliament, and Zambia, where they never pass through parliament. ${ }^{146}$ TJNA's lawsuit in Kenya concerned in part the lack of parliamentary ratification of the treaty with Mauritius: Kenya's new constitution requires parliamentary ratification of treaties, but the government argued that the tax treaty was merely an administrative agreement, a position supported by the High Court. ${ }^{147}$

In higher-income countries, it is more common—but not universal-for parliaments to approve new tax treaties. A survey of the parliamentary ratification 
of Canada's last thirty-three treaties revealed "expeditious implementation through Parliament with little or no scrutiny," with deliberations not coming to a single vote in one of the two chambers. ${ }^{148}$ In the UK, tax treaties are made law as statutory instruments, a mechanism that is designed for noncontroversial laws that are passed through a delegated legislation committee. Ratification rarely entails more than a token debate in this committee, and no treaty has ever been rejected or sent back for renegotiation. ${ }^{149}$ In Denmark, parliamentary ratification was introduced during the 1990s but is equally uncontroversial. ${ }^{150}$ At the other end of the spectrum, the US Senate is famously thorough in its scrutiny of tax treaties. It forced a change to the US-UK treaty before ratification in the 1990s, and in some cases has held up ratification altogether. ${ }^{151}$

There is certainly considerable heterogeneity across countries in the number of veto points and players. A combination of formal rules and their authoritative position could give a coherent team of tax treaty experts near-total control over the treaty-making process. Some treaty negotiators interviewed did indeed claim that ministerial and parliamentary scrutiny, where it existed, was largely a rubberstamping exercise. ${ }^{152}$ In contrast, others had been unable to realize their preferences because other stakeholders, who did not share their ideas about tax treaties, exercised a veto at various stages of the process. Even where there was no parliamentary ratification, some negotiators explained that the approval process could get held up because finance ministers did not approve signature. ${ }^{153}$

Finally, there is specific evidence that tax treaties are sometimes pushed through by nonspecialists in spite of the reticence of tax treaty specialists themselves. A study of tax treaty negotiations in Colombia, for example, suggests that tax officials received a political instruction to negotiate treaties swiftly in pursuit of "investment at any price." 154 One negotiator from a lower-income country interviewed for this book explained that his country had signed a treaty with Mauritius, a tax haven, on very disadvantageous terms because the negotiation had been initiated by the country's newly created investment promotion authority and conducted without any revenue authority involvement. The tax implications were not considered, and the country did not even formulate an opening position before beginning negotiations. ${ }^{155}$ There are numerous examples of heads of state signing agreements over the heads of their negotiating teams or instructing them to negotiate in a hurry. ${ }^{156}$

\section{Conclusion}

This chapter focused on tax treaty specialists: those who formulate international models and national policies and negotiate treaties themselves, as well as the other 
actors within their community, such as from businesses and academia. This transnational policy community has a distinct conceptualization of the role of tax treaties grounded in a set of norms concerning the appropriate way to tax multinational firms. The community wields the threat of double taxation as a tool through which to strengthen its influence over tax policymaking. The effect is to depoliticize negotiations between states that have distributional consequences, with political involvement treated as an exogenous constraint rather than an endogenous part of the policymaking process. Much of this is achieved using increasingly obscure language and elaboration of ever more detailed terms, as well as by the community's claim to authority derived from professional expertise. The community is predominantly composed of professionals from OECD countries, and this is one reason why, despite being in the majority, lower-income countries are still "norm takers" in the international tax regime.

The ability of the international tax community to exercise power within national bureaucracies varies over time and between countries. In lower-income countries, the number and experience of international tax bureaucrats varies, which is one reason for the variation in approaches to international tax: as individuals become socialized into the international tax community, their attitude toward tax treaties may changes: as they first learn about their costs and benefits framed in terms of their preexisting ideas, which may create a skeptical outlook; if they internalize the community's ideas about the desirability of convergence around OECD standards using tax treaties, it may create an enthusiastic outlook.

The influence of specialist tax bureaucrats over treaty making in a country depends further on their autonomy within the government structure. The number and nature of veto players varies between countries, and veto points may cause treaties to fail because of differing preferences over treaty partners, treaty content, or the whole project of tax treaties itself. These differences do not necessarily emerge because different actors have different material incentives, but because they hold different ideas about what tax treaties are for and, indeed, about the function of international tax rules. 